\title{
Economic Regulation and Cost Effective Infrastructure Delivery in South Africa: A Literature Survey
}

\author{
Courage Mlambo \\ PhD Candidate, Department of Economics, University of Fort Hare \\ Email:mlamboct@gmail.com
}

\author{
Doi:10.5901/mjss.2014.v5n1p195
}

\section{Abstract}

\begin{abstract}
The main objective of this paper was to come up with cost effective delivery measures for South African economic regulators. The paper drew attention to the fact that in February 2012, the President declared 2012 as the year of infrastructure delivery. The paper evaluated literature from South Africa and developing countries literature from developing countries in an attempt to observe in what way other regulators are performing. Literature on infrastructure regulation supports the need for the establishment of effective mechanisms that ensure that regulators operate in conditions that enable the provision of cost effective infrastructure. However, in South Africa, it was observed that there are also some problems that regulators face, for example, it has been seen that there is lack of coherence in the regulatory policies and regulators are inefficient. These problems make the achievement of cost effective delivery of infrastructure a difficult undertaking. It was also realized that for economic regulators to deliver costs effective infrastructure a number of measures should be implemented. These include involving private sector in infrastructure provision, increasing competition, and setting up a multi-sectoral infrastructural regulator among other things.
\end{abstract}

Keywords: Economic regulators, utility regulation, infrastructure, economic development, cost effective

\section{Introduction and Background of Study}

The role of infrastructure is crucial because it underpins development. It lays the base on which economic activities can take off from which then makes it clear that infrastructure provision is a prerequisite for economic development. It is said that infrastructure unlocks economic prospects and promotes growth. Because infrastructure drives economic development and economic growth, it is through infrastructure development that an economy can become an economic role player, both domestically and internationally. Governments should without fail provide infrastructure in order to encourage fundamental economic growth and the safeguarding of competitiveness, both in the domestic and international markets. It should be also recognized that infrastructure is not only essential for economic growth, but also for the delivery of basic services such as water and health, among other things. Social service delivery requires efficient and functioning systems of water, energy and social infrastructural services which are all essential for general human well being. Jaya (2008) maintains that an important determinant in ensuring the well-being of all citizens is the provision of adequate public infrastructure for communities, households and individuals to access publicly provided services.

Financing of infrastructure is a major problem every government faces. Resultantly, it would be worthwhile to ensure that wherever infrastructure is provided, it must be provided at a reasonable cost. Hence, there is need to ensure that infrastructure is delivered in a cost effective way to save governmental resources. When financial resources are applied it should be ensured that they are applied where they are needed. Bearing in mind that the financing of infrastructure is a burden, the South African government announced in 2012 that it will choose the most cost effective projects that could provide optimal long term benefits. This has created the need to find the best way of delivering cost effective infrastructure to lower the costs for end-users whilst making the necessary returns on investment. Cost effective supplies of basic infrastructure services such as energy, clean water, and transport is required in order to substantially develop communities. Resultantly, the provision of low-cost infrastructure is crucial to South Africa's economic growth. The importance of cost effective delivery of infrastructure calls for clarity and coherence in regulatory policies. The South African economic regulators need to take more strategic views towards the deployment of infrastructural financial resources. Regulation and regulatory institutions should be able to create a stable economic market atmosphere which encourages efficient infrastructure provision.

When the above information is taken into consideration, it should be clear that there is no easy single global 
solution for regulatory success. Different solutions can be applied with regard to local circumstances, taking into account key financial, social and environmental imperatives. A World Bank Country Study on Slovenia (1999:17) held that in order to achieve the strategic objectives of infrastructure development, a whole range of coordinated policy measures has to be designed and put into operation. These include among other things, market based policies, introduction of pricing policies that reflect real costs of production, and the establishment of a proper regulatory framework to operate public utilities. The Africa Development Group (2010), on the other hand, held that greater efforts in identifying alternative and innovative financing mechanisms for infrastructure should be directed towards enhancing private sector participation. But, without much commitment from the public sector, private sector infrastructure investment cannot succeed. The involvement of the private sector needs to be complemented with greater effectiveness in the provision of public resources. The efficient allocation of public resources coupled with collaborative private sector participation and an efficient economic regulatory system, generally should have the ability to result in lower infrastructure costs. In this instance there is need for an institutionalised setting that sets laws and rules that are the basis for successful market production, which then sets the stage for economic regulators to come into play.

However, the execution of regulatory and institutional frameworks for infrastructure services should be cautiously approached as there are many impediments in implementing infrastructure investment programmes. Regulation affects the economy in two ways; it can be productive and it can also be counterproductive if economic regulators fail to monitor the infrastructure provision process, which then can bring devastating results to the economy. Kirkpatrick and Parker (2004) argue that regulation that is too onerous will negatively affect a firm's input and output decisions and depress productivity. On the other hand, clearly stated regulatory rules within a well-defined regulatory framework can be expected to reduce 'regulatory risk' and provide incentives for private investment and this is the main objective when 'independent' regulatory bodies are established (Kirkpatrick and Parker (2004). Cost effective delivery of infrastructure can create a more certain environment for investment which can lead to more orderly economic development. This points to the need for establishment of proper methods of regulatory frameworks that lead to the delivery of cost effective infrastructure, which then forms the objective of this study.

The targets for cost effective infrastructure delivery in South Africa, should be derived from regulatory obligations and policies. Moreover, these obligations and polices require effective and sound regulatory processes to equitably target the low cost provision of infrastructure services. Inadequate and high cost infrastructure has harmful effects on the delivery of basic services and economic growth. On the other hand, low cost infrastructure costs can make a huge difference to firms on the domestic and those of the global market. A World Bank Country Framework Report on India (1996) held that the necessity for countries to compete in the global market place is putting additional pressure on countries in their efforts to provide efficient infrastructure services to their businesses in a cost effective competitive manner.

\section{The State of Infrastructure Supply and Utility Regulation in South Africa}

Investment in infrastructure has long been seen as one of the key drivers of development. It has the potential to make a major contribution to sustainable development. President Jacob Zuma, in his 2012 state of the nation address, declared 2012 to be the year of infrastructure delivery. It is clear that over the years, the government has been investing significantly in infrastructure, however there appears an immense gap been between the current supply of infrastructure services and the needs of South Africans. This has been realised by the government and state enterprises, and a number of infrastructure projects have been put in place. This section reviews the infrastructure projects that have been put in place and it also, briefly, assesses the developments in the regulatory framework of South Africa.

\subsection{Energy sector}

South Africa's energy sector is regulated and mostly publicly-owned. The energy sector is regulated by National Energy Regulator of South Africa (NERSA) and energy sub-sectors are dominated by a single or a few of large firms. The United Nations Conference on Trade and Development (UNCTAD) (2010) notes that Eskom, a publicly owned operator, dominates the electricity sector and in the petroleum sector there is Sasol, PetroSA and international oil companies. Sasol is also in the piped gas sector, and Transnet Pipelines is in the petroleum pipelines sector. Although there have been noteworthy reforms in the energy sector, there are still problems within the electricity sector.

The UNCTAD (2010) held that the results of the reform process in the electricity sector still remain to be seen in terms of competition inducing effects, and foreign investments which have been slow to materialize (not surprisingly 
considering Eskom's role as single buyer and the lack of appropriate legislation). Eskom's dominance in the electricity sector has been blamed for the problems in the energy industry. This has resulted in electricity shortages as Eskom alone cannot meet the rising demand for electricity. Lack of infrastructure coupled with ageing infrastructure is one of the problems that have led to electricity shortages in South Africa. Resultantly, the South African government has a vital role to play in solving the energy crises through infrastructure development programmes. The government announced infrastructure programmes that could help in the delivery of electricity and some of these programmes are listed in figure 1 below.

Figure 1: Major Infrastructure projects (Energy)

\begin{tabular}{|c|c|c|c|}
\hline $\begin{array}{c}\text { Project name/ } \\
\text { Implementing agent }\end{array}$ & $\begin{array}{c}\text { Total project cost } \\
\text { R billion }\end{array}$ & $\begin{array}{c}\text { Project objective and completion } \\
\text { target date }\end{array}$ & Status \\
\hline Kusile power station (Eskom) & 121.0 & $\begin{array}{c}\text { Build 4 800MW coal-fired power } \\
\text { station, first unit commissioned by } \\
2014\end{array}$ & Under construction \\
\hline $\begin{array}{c}\text { Renewable energy } \\
\text { (independent } \\
\text { power producers) }\end{array}$ & 120.0 & $\begin{array}{c}\text { 3 725MW of renewable energy } \\
\text { procured into national grid by 2016 }\end{array}$ & $\begin{array}{c}\text { Tender process under way, 1 415MW } \\
\text { of bids in first procurement round } \\
\text { confirmed }\end{array}$ \\
\hline $\begin{array}{c}\text { Distribution backlog (Eskom } \\
\text { and } \\
\text { municipalities) }\end{array}$ & 27.5 & $\begin{array}{c}\text { Refurbishment and new distribution } \\
\text { Network }\end{array}$ & Ongoing progmme \\
\hline $\begin{array}{c}\text { New transmission lines } \\
\text { (Eskom) }\end{array}$ & 95.0 & $\begin{array}{c}\text { Upgrade and new transmission lines } \\
\text { over 5 years }\end{array}$ & Work in progress \\
\hline \begin{tabular}{c} 
Medupi power station (Eskom) \\
\hline
\end{tabular} & 99.0 & $\begin{array}{c}\text { Build 4 788MW coal-fired power } \\
\text { station, first unit commissioned by } \\
2013\end{array}$ & Under construction \\
\hline
\end{tabular}

Source: South African Revenue Service (2012)

Figure 1 shows how the South African government and state enterprises have improved attempts to increase economic infrastructure investment. Key projects will include the established of the Kusile power station and the Medupi power station and other electricity generation schemes. Access to electricity is also expected to be increased through upgrading and setting up new transmission lines over 5 years. There will also be refurbishment and new distribution networks. The government has pledged it full commitment in the investment of infrastructure that would in turn help in electricity generation.

\subsection{Telecommunications sector}

South Africa has the most thoroughly developed telecommunications infrastructure on the continent. However, there is still need to achieve the goal of quality and affordable telecommunications and this requires additional investment in telecommunications infrastructure. Several infrastructure projects that have been lined up and some are up and running. Some of them are listed in figure 2 below:

Figure 2: Major Infrastructure projects (Telecommunications sector)

\begin{tabular}{|c|c|c|c|}
\hline $\begin{array}{c}\text { Project name/ } \\
\text { Implementing agent }\end{array}$ & $\begin{array}{c}\text { Total project cost } \\
\text { R billion }\end{array}$ & $\begin{array}{c}\text { Project objective and completion } \\
\text { target date }\end{array}$ & Status \\
\hline $\begin{array}{c}\text { Digital terrestrial television } \\
\text { (Sentech) }\end{array}$ & 0.8 & $\begin{array}{c}\text { Start analogue terrestrial network by } \\
\text { December } 2013\end{array}$ & $\begin{array}{c}\text { Signal testing phase recently } \\
\text { completed }\end{array}$ \\
\hline $\begin{array}{c}\text { National wireless broadband } \\
\text { network (Infraco) }\end{array}$ & 1.0 & Acquire additional broadband capacity & Cables are being laid \\
\hline
\end{tabular}

Sources: South African Revenue Service (2012)

Figure 2 shows two projects that have are supposed to improve telecommunications infrastructure. The projects shall be 
run by Digital terrestrial television and the National wireless broadband network respectively.

\subsection{Transport sector}

Investment in transport infrastructure is vital for economic growth. It is also needed in the case of South Africa competing in international markets. South Africa's transport infrastructure is ageing hence there is need for it to be modernized so as to increase economic growth. A number of projects have been lined up to help maintain, improve and put new transport infrastructure. Some of the projects appear on Figure 3.

Figure 3: Major Infrastructure projects: Transport

\begin{tabular}{|c|c|c|c|}
\hline $\begin{array}{c}\text { Project name/ } \\
\text { Implementing agent }\end{array}$ & $\begin{array}{c}\text { Total project cost } \\
\text { R billion }\end{array}$ & $\begin{array}{c}\text { Project objective and completion } \\
\text { target date }\end{array}$ & Status \\
\hline Passenger railways (PRASA) & 80.0 & $\begin{array}{c}\text { Acquire a new fleet of rolling stock } \\
\text { over 20 years }\end{array}$ & $\begin{array}{c}\text { Procurement has } \\
\text { commenced }\end{array}$ \\
\hline $\begin{array}{c}\text { National road improvements } \\
\text { (SANRAL) }\end{array}$ & 45.4 & $\begin{array}{c}\text { Maintenance improvements, refurbishment and } \\
\text { new roads }\end{array}$ & Work in progress \\
\hline $\begin{array}{c}\text { Provincial road improvements } \\
\text { (Provincial Department of } \\
\text { Roads) }\end{array}$ & 25.5 & $\begin{array}{c}\text { Maintenance, refurbishment and new roads over } \\
\text { next 3 year }\end{array}$ \\
\hline
\end{tabular}

Sources: South African Revenue Service (2012)

The government remains committed to the transport investment plan as shown by figure 3 above. Figure 3 shows that the Passenger Rail Agency of South Africa (PRASA) shall invest over R80 billion rands in acquiring a new fleet of rolling stock and this is expected to improve the quality of services and it will also promote higher safety levels of passengers. Plans also indicate that government provincial departments shall spend almost R25bn in transport infrastructure. Particular attention shall be given to the maintenance of provincial and rural roads. National roads shall be taken care of by the South African National Roads Agency (SANRAL) which shall spend R45bn on new roads, road maintenance and infrastructure. This investment in transport infrastructure is expected to promote economic competitiveness and in turn lead to sustained economic growth.

This section reviewed the developments in some infrastructure sectors. It showed government and state enterprises plans in investing in infrastructure and financing infrastructure projects. These initiatives are expected to assist the country to meet its goal of economic growth and development. This calls for economic regulators to ensure that the infrastructure provision process is done in a cost effective manner. The delivery of cost effective infrastructure is determined by the way economic regulators translates the goals and legal objectives into operating rules, with the aim of bringing about investment, efficiency and service quality. Literature on infrastructure regulation supports the need for the establishment of effective mechanisms that ensure that regulators operate in conditions that enable the provision of cost effective infrastructure. The next section looks at studies that attempted to investigate the regulatory environment in infrastructure services provision.

\section{Economic Regulation in Infrastructure Industries: Findings from Studies}

The role of and impact of economic regulation in infrastructure industries have been investigated by a number of studies. These studies are discussed below.

\subsection{Empirical literature from Developing countries}

This section looks at literature of what is done in developing countries. Assessing literature from developing countries helps to observe in what way other regulators are performing. In addition to this, it helps in finding ideas and solutions that might be useful to South Africa.

Wallsten (1999) made use of information from 30 countries in Africa and Latin America from the years 1984 to 1997. Using a range of physical quality indicators, such as main line penetration, telecom employees per main line and the price of a three-minute local call, the impacts of liberalization were studied through competition, privatization and 
conduct regulation. Wallsten (1999) found that competition had tangible benefits on performance and that privatization combined with the establishment of conduct regulation had a positive impact on performance. Zhang, Parker and Kirkpatrick (2003) used panel data for 51 countries in Africa, Latin America, the Caribbean, and Asia over the period 1985 to 2000. The study confirms the importance of competition and/or effective independent regulation if economic performance is to improve, following privatisation. In another study, Eberhard (2006) summarized the experiences of regulation in developing countries over the past one and a half decade and explores ways of improving the design and performance of regulatory systems. Some of the problems and challenges with existing regulatory models identified in the study include weak regulatory commitment, institutional fragility, lack of transparency and legitimacy, and lack of capacity and competence. Eberhard (2006) proposed various further ways of strengthening regulatory performance, including mandated periodic reviews of regulators, building the demand-side for regulatory transparency and capacity building.

Andres, Guasch and Straub (2007) evaluated the impact of economic regulation on infrastructure sector outcomes. In their study, the impact of regulation from three different angles was tested. These angles were; aligning costs with tariffs and firm profitability; reducing opportunistic renegotiation; and measuring the effects on productivity, quality of service, coverage, and prices. Finding proves out that regulation matters. Their study revealed that significant efforts should be made to develop the value, structure, and institutionality of regulation. In addition to this, their study showed that, regulation matters in order to protect investors and consumers, for aligning closely financial returns and the costs of capital, and for capturing higher levels of benefits from the provision of infrastructure services by the private sector.

Correa, Melo, Mueller and Pereira (2007) conducted a study in Brazil. They observed that the impact of regulation on the economic performance of regulated sectors depended mainly on the appropriateness of the design of the regulatory agencies' structure and process, that is, on regulatory governance. To them, governance refers not only to the policies that emerge from regulation, but rather to the inputs that go into the regulatory process. Their study identified key components of regulatory governance, namely, autonomy, procedures for decision making, instruments and accountability, which were then used to set up an analytical framework for measuring regulatory governance in Brazil.

Patel and Bhattacharya (2009), in their study in India, noticed that the Indian infrastructure was in a state of flux; the provisioning of infrastructure services in India was seen as steadily moving away from the realm of government to that of the private sector. The important issue had been to rectify economic structures in those sectors where there have been a recognition (and systemic implementation) of the principles of appropriate market structures, competition, and measured regulatory oversight. Indian telecom provided services that are globally cost-effective and that the provision of electricity remained problematic for consumers and appeared to be a major bottleneck for India's continuing growth.

Studies in developing countries show that regulation is of utmost importance but weaknesses appear in the manner with which the regulatory framework is structured. Studies assessed show that there is need for effective governance, competition, building the demand-side for regulatory transparency and capacity building, and many other measures that can improve the effectiveness of economic regulation in developing countries. The South African economic regulators need to take more strategic views towards the deployment of infrastructural financial resources.

\subsection{Empirical literature from South Africa}

Van Basten (2007) argue that the main weaknesses across regulators include among other things lack of policy coherence, piecemeal development of regulation on a sector-by-sector basis, lack of limited regulatory independence, weakness in terms of internal governance models of regulators. Van Basten (2007) cites human resources capability as one of the obstacles in the National Energy Regulator which includes interference by the government. Van Basten (2007) also mentions the government's seemingly indecisiveness on certain policy issues, for example investment in electricity generation infrastructure which has created significant uncertainty.

Stenyn (2011) held that in many areas regulatory practice has continued to develop and the quality of decisions has improved. The study indicated that regulatory practice has also contributed to a more pointed debate about the trade-offs to be made in large infrastructure investment decisions. Regulators have also acted as an important check on the more extreme aspects of behaviour by senior officials or even ministers (Stenyn, 2011). The study also identified some weaknesses of regulators which are; the ineffectiveness of regulators in preventing monopoly abuse, the dominance of infrastructure state owned enterprises (SOEs) in the parts of the sector value chain that they operate in. In addition to this, the study also observed that regulatory decisions were sometimes unpredictable, arbitrary or of poor quality. Stenyn (2011) argues that Mayer and Onyango (2005) conducted a literature based review of economic 
regulation in South Africa. Their paper highlighted the finding that regulatory frameworks are established and managed on a sector-by-sector basis and suggested that there is a need for a single regulatory framework for the regulation of administrative price setting.

Recent studies show that regulatory frameworks are now established and regulators have improved significantly. However, regulators are still facing problems. Efficient regulatory frameworks have been identified as being critical to the proper functioning of the South African infrastructure regulation sectors. It was also realized that regulation indeed matters in South Africa. Although there have been improvements in the regulatory environment, there are still shortfalls in the operation of regulators. Studies show that regulators still face problems that can make the delivery of cost effective infrastructure nearly impossible and these are:

(i) Regulators are not effective in preventing monopoly abuse - South African regulators have not been effective in preventing monopoly abuse. This has resulted in shortages, especially in the electricity sector where Eskom is a monopoly. Eskom's monopoly position has led to lack of capacity in the generation of electricity and infrastructure. This has in turn made Eskom to be unable to keep up with demand.

(ii) Skills shortages - South Africa is faced with a problem of having an excess supply of unskilled labour and a shortage of skilled a workforce. The regulatory environment is not an exception to this problem; it is faced with a limited supply of skilled personnel. Only skilled personnel are able to produce cost effective measures in the process of infrastructure provision. Without skilled people, it would be difficult to deliver infrastructure in a cost effective way.

(iii) It has also been found that lack of regulatory policy that emphasizes competition exists. Unfortunately, there are no defined competition laws in the regulation environment and this has led to the dominance of a handful of large firms in the different regulatory sectors.

(iv) Lack of private sector participation in some other sectors partly caused by inadequate regulatory framework also occurred. Private participation has not been encouraged and this has resulted in inefficient electricity generating capacity in the energy sector.

When the above information is taken into account, these are not the only problems that South African regulators are facing. There are also some problems that regulators face, for example, it has been seen that there is lack of coherence in the regulatory policies. These problems make the achievement of cost effective delivery of infrastructure a difficult undertaking. The next section outlines the recommendations that would make the delivery of cost effective infrastructure possible. It outlines ways of delivering cost effective infrastructure to lower the costs for end-users whilst making the necessary returns on investment.

\section{Recommendations}

An analysis of studies conducted by this study showed that success of regulatory reforms has been mixed across countries. This indicates that there is no simple mechanism or solution for success for the regulation of infrastructure or economic regulation in general. Learning from international experience is vital, but local conditions should be kept in mind. What may be good in another country might not be good in another, hence there is need to take local circumstances in consideration. The pitfalls that regulators have a number of policy implications hence there is need for South African economic regulators to attempt to facilitate the delivery of cost effective infrastructure. The delivering of cost effective infrastructure can be done in the following number of ways:

\subsection{Utility Regulators must be insulated from political pressures}

Regulatory goals are distorted to pursue political ends when there are political pressures. When regulators are subject to direction from political authorities, they might be directed toward achieving political goals. Political authorities usually have short term political considerations and these usually result in corruption. Corruption is costly; it diverts resources from economic development, moreover it will lead to high cost infrastructure provision. Rosberg and Jackson (1982) assert that corruption is invited by the state apparatus, which contains both resources and opportunities for corruption and rules and regulations which can be abused for personal or private advantage. The delivery of essential infrastructure requires transparent, effective and efficient government and regulatory processes to avoid being hindered by bureaucracy.

It is also recommended that the infrastructure regulatory environment should be in such a way that it does not become a hot spot for dishonest activities and unscrupulous opportunists. The decision-making process of an 
independent regulator should be transparent so as to help protect against politically expedient decisions.

\subsection{Regulators should make efforts to promote competition by limiting anti-competitive behaviour}

An important measure for cost effective provision of infrastructure services is the introduction of competition wherever possible. Many infrastructure services can be provided in a competitive market. However, regulatory measures should be taken to protect consumer interests. When assuring the potential for competition, the relevant market needs to be considered in a broad sense, taking into account potential competition from substitute products. Competition can take two forms:

(i) Competition within the market - where firms compete to supply the same services and,

(ii) Competition for the market - where firms compete for the right to provide services for a given period of time under contract or concession.

When promoting competition, regulators should establish the necessary governance arrangements that would create a favourable market form. They can, firstly, design the appropriate market form and then produce regulatory mechanisms that are suitable for that market form. Competition is needed, for example, in the electricity sector where Eskom is a monopoly.

\subsection{Regulators should involve the private sector in infrastructure provision}

Cost effective infrastructure investment by the government alone will be to no avail, unless the private sector plays a role in delivering infrastructure. As a rule, there should be progress across all sectors and a strong relation between economic regulators and the private sector should be established. The presence of the private sector supplements the state's capacity to build and operate infrastructure. It was found that the private sector has been making a significant independent contribution to infrastructure funding in telecommunications, airlines, and many other services. However the private sector participation still lacks in some sectors.

\subsection{Setting up a multi-sectoral infrastructural regulator}

The establishment of a multi-sectoral regulatory agency is needed for South Africa to provide cost effective infrastructure. Having separate regulatory agencies for each sector is costly, therefore it would be worthwhile to have a multi-sectoral regulatory agency. The experience of Jamaica, the United States and other countries has revealed advantages of the multi-sector regulator model. Multi sector regulation can make the better use of scarce human resource possible; they also make the management of firms operating in more than one sector much easier. Multi-sectoral regulation help promote consistency of approach. All these would eventually lead to cost reduction. In addition to this, a multi-sectoral regulator will not be vulnerable to political capture, because it would be covering many different sectors administered by different ministries.

\subsection{There should be a periodic Regulatory Impact Assessment}

There should be a process of periodically assessing the benefits and costs of economic regulation. Periodic monitoring and evaluation of the infrastructure regulation process is a powerful mechanism to build the competence and efficiency of regulatory institutions. Mandatory, periodic, independent reviews of regulators should be recommended to hold independent regulators accountable.

\subsection{Regulators should periodically review of the infrastructure provision process}

Regulators should periodically review the infrastructure provision process to allow for more frequent adjustments to avoid the mismatch between cost changes and tariff adjustments. A regulated company may face significant costs that are both uncertain and largely outside its control. Costs of purchases on international markets may be affected by currency devaluation. Hence, there is need to make frequent adjustments to enable firms to make the necessary returns on investment. 


\subsection{Education and training}

Investment in education and training at all levels must be a priority for regulators. Skills and an able bodied workforce will drive the future development of infrastructure in South Africa. It is critical that the infrastructure industry, in cooperation with the government, develops mechanisms to ensure that the skills required for infrastructure projects in South Africa exist. The government offers an infrastructure skills development grant but there is need for more intense skills development. Performing many tasks in infrastructure regulation requires technical skill and expertise. Administering pricing rules and other forms of regulation requires skills in law, microeconomics and finance. The quality and credibility of regulatory decisions depends in large measure on the competence of regulatory staff. There is no doubt that a competent workforce will lead to cost efficiency which will result in the provision of low cost infrastructure.

\subsection{Government transformation}

For efficiency in the infrastructure provision process, there is need for the government to be transformed from government into governance. Since the Minister is the one who appoints regulatory officials, he/she must have apolitical interests. Rather they should make decisions that seek to promote the general welfare. This requires some transformation from government into governance. Governance is the apolitical and efficient decision making practices that have the interest of the people at heart. If there is proper governance then regulators will be free from improper pressures or inducements from government officials.

Greater efforts in identifying other innovative cost reducing mechanisms for infrastructure should be done. Such efforts will have to go together with greater efficiency in the functioning of regulators, the government, state enterprises and other relevant stakeholders. Regulator must also be cautious on quality; they must ensure that firms avoid skimping on quality. Firms can skimp on quality to reduce operating costs. This calls for parallel regulation of quality and durability of the infrastructure.

\section{Conclusion}

The paper showed that cost effective infrastructure regulation is the key to infrastructure reform. Economic regulation must strike a balance between consumers, government and investors. Consumer welfare should be maximized through the provision of services at the lowest necessary price. Literature on economic regulation was assessed and it supports the need for the establishment of effective mechanisms that ensure that regulators operate in conditions that enable the provision of cost effective infrastructure. In South Africa, it was observed that there are also some problems that regulators face, for example, it has been seen that there is lack of coherence in the regulatory policies and regulators are inefficient. These problems make the achievement of cost effective delivery of infrastructure a difficult undertaking. The paper also reviewed the developments in some infrastructure sectors. It showed government and state enterprises plans in investing in infrastructure and financing infrastructure projects. Government and state enterprises initiatives are expected to assist the country to meet its goal of economic growth and development. It was also realized that for economic regulators to deliver costs effective infrastructure a number of measures were recommended. These include involving private sector in infrastructure provision, increasing competition, and setting up a multi sectoral infrastructural regulator among other things.

\section{References}

Africa Development Group (2010), Infrastructure Deficit and Opportunities in Africa. [Online] Available: http://www.afdb.org/fileadmin /uploads/afdb/Documents/Publications/ECON\%20Brief_Infrastructure\%20Deficit\%20and\%200pportunities\%20in\%20Africa_Vol \%201\%20lssue\%202.pdf. (June 10 2012)

Andres, L., Gash, J.L, and Straub, S. (2007). Do Regulation and Institutional Design Matter for Infrastructure Sector Performance? Latin America and the Caribbean Region. Washington DC: The World Bank,

Correa, P., M.A. Melo, B. Mueller and C. Pereira. (2007), Regulatory Governance in Brazilian Infrastructure Industries. [Online] Available:https://openknowledge.worldbank.org/bitstream/handle/10986/7059/363060Regulato101official0use0only1.pdf?sequen ce=1. (June 10 2012)

Eberhard, A. (2006), Infrastructure regulation in developing countries: an exploration of hybrid and transitional models. [Online] Available: http://www.ppiaf.org/sites/ppiaf.org/files/publication/AFUR_hybrid_and_transitional_models_ebhart_paper_0.pdf. June 102012.

Égert, B. (2009), Infrastructure Investment in Network Industries: The Role of Incentive Regulation and Regulatory Independence. 
[Online] Available: http://papers.ssrn.com/sol3/papers.cfm?abstract_id=1400615. (June 10 2012)

Gasmi, F, Um, P.N, and Virto, L.R. (2009), Political Accountability and Regulatory Performance in Infrastructure Industries: An Empirical Analysis [Online] Available: http://wber.oxfordjournals.org/content/23/3/509.short. (June 04 2012)

Jackson, R.H., and Rosberg, C.G. (1982). Personal Rule in Black Africa: Prince, Autocrat, Prophet, Tyrant. USA: University of California Press

Jaya, J. (2008), The Intergovernmental Context of Municipal Infrastructure Grants in South Africa. [Online] Available: www.Idphs.org.za/publications/publications-by-theme/local-government-in-south-africa/financial-management/Assessing\%2520. (June 04 2012)

Kerf, M and Smith, W. (1996). Privatising Africa's infrastructure: Promises and Challenges. Washington DC: World Bank

Kirkpatrick, C and Parker, D. (2004), Infrastructure Regulation: Models for Developing Asia. ADB Institute Discussion Paper No. 6 [Online] Available: www.adbi.org/files/2004.05.06.dp006.infrastructure.asia.pdf. (June 04 2012)

Mayer, M. J., \& Onyango, D. (2005). Review of Regulation In South Africa. Pretoria: Human Sciences Research Council

Patel, U,R,and Bhattacharya, S. (2009), Infrastructure in India: The economics of transition from public to private provision. [Online] Available: www.hss.iitm.ac.inrtppp/PPPs/Journal\% 2520articles/Infrastructure\%2520in\%. (June 25 2012)

Steyn, G. 2011, The impact of economic regulation on the management and performance of State Owned Enterprises. Prepared for the Presidential State Owned Enterprises Review Committee. [Online] Available: www.meridianeconomics.co.za/wpcontent/uploads/2012/04/. (June 25 2012)

South African Revenue Service. 2012, National Budget Review. [Online] Available: http://www.sars.gov.za/home.asp?pid=75313. (June 05 2012)

The Africa Development Group. 2010, Infrastructure Deficit and Opportunities in Africa: Economic Brief. [Online] Available: www.afdb.org/en/knowledge/publications/economic-briefs/. (June 17 2012)

United Nations Conference on Trade and Development. 2010, Selected Country Experiences with Regulatory and Institutional Aspects of infrastructure Services. Draft paper for the Multi-Year Expert Meeting on Services, Development and Trade: The Regulatory and Institutional Dimension. [Online] Available: www. unctad.org/en/docs/c1mem3d6_en.pdf. (July 3 2012).

Van Basten, C. 2007, Economic Regulation and pro-poor market development. [Online] Available: www.value-chains.org /dyn/bds/docs/574/VanBasten.pdf. (June 14 2012)

Wallsten, S.J. (1999). Competition, privatization, and regulation in telecommunications markets in developing countries: An econometric analysis of reforms in Africa and Latin America. Washington: The World Bank

World Bank infrastructure Report: India. (1996). Policy and imperatives for growth. New Dehli: Thomson Press

World Bank Country Study on Slovenia. 1999. Slovenia: Economic Transformation and EU Accession. Washington: World Bank

Zhang, Y,F., Kirkpatrick, C. and Parker, D. (2003). Competition, Regulation and Privatisation of Electricity Generation in Developing Countries: Does the Sequencing of Reforms Matter? Manchester; Centre on Regulation and Competition: University of Manchester. 
